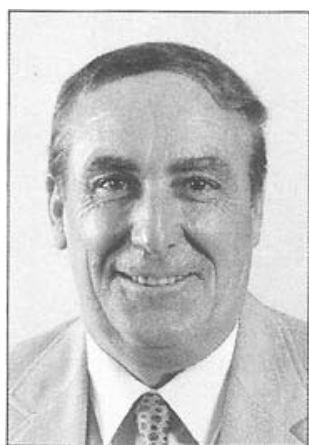

\author{
Seymour D. Van Gundy, Dean \\ College of Natural and Agricultural Sciences \\ UC Riverside
}

\title{
Land grant model: Help for the new Russia
}

During February I spent 10 days as a guest of the Russian Academy of Sciences' Biological Research Center (BRC) at Pushchino, a science city of 20,000 about 75 miles south of Moscow. One of Russia's premier research centers with a current focus on biotechnology, the BRC is developing a new mission. It is giving serious consideration to launching an agricultural research and extension effort patterned after that of the U.S. land grant universities.

Our delegation to Pushchino included faculty from the University of California and Washington State University, as well as representatives from the federal government and the private sector. Our purpose was to help the BRC contribute to economic change and development in Russia. We focused on four strategies: sustaining and enhancing the scientific excellence of BRC; developing technology and information to meet private sector and economic development needs; technology transfer; and commercialization of technology to the private sector.

The need for these changes is great, because the shift from communism to a more market-oriented economy is causing enormous stress at all levels of society. The best way to illustrate the economic dilemma of the Russian people is to imagine your $\$ 100$ bill for monthly grocery purchases turning into a $\$ 1$ bill - at the same time that food prices increase fivefold.

There is no question that the U.S. must help the Russians through this economic crisis as an alternative to the cold war. The issues are too many to address in this column, so I will focus on two for which I have some expertise and personal interest: the need to save Russian science as a world resource, and the need to provide technical assistance to the Russian agricultural industry as a key to political stability.

Currently, the U.S. government is focused on supporting nuclear scientists for fear they may migrate from Russia to renegade countries. The spiraling decline of the ruble has reduced researchers' salaries to the equivalent of $\$ 10$ per month. Present levels of funding for the academy's institutes will decline after March, when staff will be cut and "unproductive" institutes closed. Many institutes have been told to become more business oriented by doing contract research, developing joint ventures with the private sector, and marketing products developed by the institutes.

U.S. companies and federal agencies supporting research have an opportunity to contract for research in Russia for a fraction of the cost in the U.S. Some universities are using federal funding to form "sister laboratories" with Russian institutes. The U.S. should seize on this opportunity by helping Russian science link with American science in a creative and collaborative way. Otherwise, the world risks losing a unique scientific resource.
In response to our visit, the $B R C$ has developed links with the Ministry of Agriculture, the States of Moscow and Vorenezh, and the City of Pushchino as part of a mission to support the privatization of agriculture by providing training, public service, and technology transfer. In the last 50 years, 800,000 villages have been abandoned on 12 million hectares of land. There are now 61,000 private farmers and 250,000 applications for new private farming operations.

The government has evaluated its state farms, and those classified as "unproductive" are being privatized. The "productive" state farms will remain unchanged for the moment to insure a stable food supply until the private farms are able to stand on their own. However, the well established monopolistic state farms will make it difficult for the private farms to succeed without supplies and markets. Furthermore, privatization of allied agribusinesses has not taken place. In one extreme example, a simple hammer must be issued by the state. Even on state farms, equipment is not being replaced and it appeared that other equipment was cannibalized to keep the farm in operation. Food processing equipment was old and outmoded.

In the coming year, the entire food production system must be rebuilt, from seed stocks to marketing. Without plentiful food stocks next year, there may be no political and economic stability to reduce the potential of something worse than the cold war.

U.S. land grant universities have an opportunity to provide technical support and training in all segments of the agricultural and agribusiness industry. The new Russian private farmers have no experience managing the entire farming and marketing system. In addition, those farmers are not educated in the latest technology. Many do not have access to it. On the other hand, the new private farmers are a tough, gritty lot, instilled with self confidence and a willingness to work long hours for themselves. They are convinced that "anything is possible." With help they will survive and succeed in this new Russia.

The University of California can assist not only these individual farmers but, by helping Russians to recreate the land grant model, contribute to the long-term economic vitality and political stability of that nation. The foundation has been laid by a protocol of intention signed by the Russian Ministry of Agriculture, the Moscow Region, the Pushchino BRC, and both UC and WSU. We have taken an important first step to protect some of Russia's unique scientific resources, foster creative collaboration between our two countries, and ensure the political stability of the new Russia.

Seymour Van Gundy is Dean, College of Natural and Agricultural Sciences, and Director of ANR Programs, UC Riverside. 